formed lizard, I thall jus: mention a third endenvour wbich has been made to explain the black colour of the lizards inhabiting small islets.

In his interesting book, "Beiträge zur Descendenz-Theorie," Leipzig, 1876 , Seidlitz has tried to introduce the belief that the black colour serves as an armour or protection to the animal against the burning rays of the sun. Thereupon I sought to prove that reptiles inhabiting the desert would need such a protection more than the others, yet they are not black.

As some might perhaps draw, from what I have said, the conclusion that, according to my hypothesis the reptiles of the desert should be also black, I must remark that the scorcbing rays of the sun in the desert effect so strong $\mathrm{n} n$ elevation in the temperature of the soil, that it brings forth a relaxation in the animal, and slackens the energetic movement of the pigment, consequently the extreme heat counteracts the effect which the light produces, whilst on the islets of the Mediterranean the heat is alleviated by the sea breezes and by a certain degree of dampness. As we already know, all our European species of lizards carefully avoid the desert.

The darlk-coloured lizards at present known, which inhabit small islands, are the following ones :-

1. Lacerta muralis, var. archipelagica, De Bedriaga: "Die Faraglioni-Eidechse." (Heideiberg, I876; pp. 19.) L. mantalis, var. B. Erhard: "Fauna der Cyliladen," (Leipzig, I858; pp. 8o.) L. muralis, var. C., Schreiber: "Herpetologia europæa." (Braunschweig, 1875 ; pp. 408.) L. muralis, var. archipelagica, v. Bedriaga : "Herpetologische Studien," im Archiv fïr Natur. seschichte, 1878 .

Back and extremities black, covered with rows of green spots. Belly and tail black. Inhabits the Cyclades.

2. Lac. Muralis var. melisellensis, Braun: Lacerta lifford and L. muralis ; "Arbeiten aus dem zoolog. zootom. Institut in Würzburg, 1877."

Back brown, ornamented with six light longitudinal stripes. Belly dark blue, chin rather lighter. Length $130 \mathrm{~mm}$. Inhabit the islet Melisello near the island of Lissa, in the Adriatic Sea.

3. L. mutralis, var. filfaensis, De Bedriaga : "Die Faraglioni Eidechse." (Heidelberg, 1876.) Braun, l.. v. Bedriaga "Herpetologische Studien," in Archiv f. Naturg., I879, Guinther : "Description of a new European Species of Zootoca," Annals and Magazine of Natural History, 1874.

Back black covered with small green spezks, the under parts are deep blue. Length $212 \mathrm{~mm}$. Inhabits Filfla, near Malta.

4. L. Mnuralis, var. faraglionienssis, De Bedriaga: "Ueber die Entstehung der Farben bei den Eidechsen." (Jena, 1874.) L. musalis zar. corrulce, Eimer: "Zoologische Studien au Capri." (Leipzig, I874.) Braun, l.c.

Back black, the sides blue spotted with black; the belly a brilliant blue. Length $220 \mathrm{~mm}$. Inhabits the Faraglioni Rock, near Capri.

5. L. mutralis, var. Latastei, De Bedriaga: "Herpetologische Studien," in Archio f. Naturg., I879, pp. 264.

Back and sides brown, or dark brown covered with black spots, sometimes with bluish green spots on the sides. Above the root of the forelegs a bluish spot. Length $205 \mathrm{~mm}$. In habits Ponza near Gaeta.

6. L. muralis, var. Lilfordi, Giinther: "Description of a New European Species of Zootoca," l.c. Braun, l.c.

Upper parts of a deep glossy black, lower parts of a beautiful sapphire blue. Length $175 \mathrm{~mm}$. Inhabits the Island of Ayre, near Minorca.

7. L. muralis, var. Giglioiii, De Bedriaga: "Herpetologische Studien," I879, l.c.

Forepart of the back covered with alternately green and blue stripes. The hind part of the back is dark blue. The sides are light brown with green and blue spots. The belly brick-red with (sometimes without) small blie stripes. Colouring varies. Length $175 \mathrm{~mm}$. Inhabits Isla del Dragoneras near Majorca.

8. L. muralis, var. Rasquineti, De Bedriaga: "Herpetologische Studien," 1878 , l.c.

Back olive brown with a black pattern. Blue eye-spots ornament the sides. Belly brick-red. The first longitudinal rows of the ventral scales are blue. Length $185 \mathrm{~mm}$. Inhabits the islet La Deva near Arnao (Spain).

Heidelberg, August 28

\section{Insect Swarms}

THIs year being remarliable for "insect swarms," it is important that all possible information about them should be gained, so as to satisfactorily account for these phenomena. As to Vanessa cardui, which has been abundant throughout the spring and summer, it is possible that some of those specimens which occurred in the spring were the result of a migration from the Continent, but there is no doubt that the specimens which are now seen are nearly, if not all, bred in this country from ova de. posited by the spring specimens, quite sufficient time having elapsed for the metamorphosis. With regard to Pinsia gamma, I am of opinion that all the specimens seen, and they have been in profusion here from about August io till the present time, have been bred in this country. My reason for so believing is that the larvæ were most abundant in the spring, doing damage in gardens to a great extent. Some of these larva I fed up, the perfect insects emerging at the time $P$. gamma first appeared in abundance. My experience of the swarms of $P$. gamma is that they moved in no particular direction, merely passing in numbers from flower to flower, flowers being scarce this year, any apparent migration being simply a search for more flowers. Instead of putting the canse of these swarms down to "migration," endeavours should be made to discover the causes of the extraordinary periodical fecundity. It is quite probable, too, that next year, $P$. gamma and $V$. cardui will be scarce, as is frequently the case with Colias edusa and hyale after a year of abundance.

Lewes, September 13 J. H. A. JENNER

\section{Earthquakes}

I HAVE observed, in several recent numbers of NATURE, various notices of earthquakes, so frequent as to suggest the idea to me (perhaps incorrect) that for several months past they have been more numerous than wrinal. Since my arrival in West Java I have experienced several scvere shocks. On March 28, between 7 and 8 P. M. I was startled by a peculiar shivering as I sat in my chair. At first I imagined I was seized with a terrible feverless ague, but I was soon undeceived by the increased bumping and the clashing of my bottles, \&c., and the vehement beseeching of Tukan Allah, and the lond exclamations of the natives of, "VTe are here!" "We are all here!" I learned in a few days that several villages lying at the base of the peccant volcano, Gedè, had suffered; in particular the town of Ijandjoer, in which numerous houses were destroyed, many bridges broken down, the telegraph apparatus entirely thrown out of gear, and six or seven persons linlled. The ground also opened and emitted volumes of smoke, while the Gede itself burst out with extra vigour, throwing out, in addition to the usual white steamy vapour, large quantities of smolie and ashes, fortunately to no great distance. Throughout the 28 th and 29 th there was a sticcession of shocks. On June 3 I experienced a second earthquake, inndulatory but not very severe ; and again on the 5 th, undulatory, of consiclerable duration, and severe enough to thoroughly shake the whole house and throw down unfixed objects. These have done no damage to life, as far as I have heard, and, beyond some houses being cracked in Batavia, little to property. Since the beginning of March there have been numerous shocks, but mone so violent as those of March 28 and June 5. Immediately preceding the shock of June 5 there was a sudden and heavy fall of rain, the drops being very large. The direction of the wave was from east to west.

Kosala, Bantam, July

\section{Leaping Power of Mantis ${ }^{1}$}

I CAN state from my own observations of several different species, both in Ceylon, South Africa, and Fiji, that the power is possessed by many, chiefly in the larval stage, and that the distances they can spring from branch to branch are very considerable for the size of the insect.

British Consulate, Noumea

E. L. LAYARD

\section{OUR ASTRONOMICAL COLUMN}

The OUter Satellite of MaRs.-The following positions of Deimos, the exterior satellite of Mars, are deduced from the data published in Prof. Asaph Hall's memoir, in which he determines the elements of the satellite-orbits :-

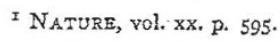




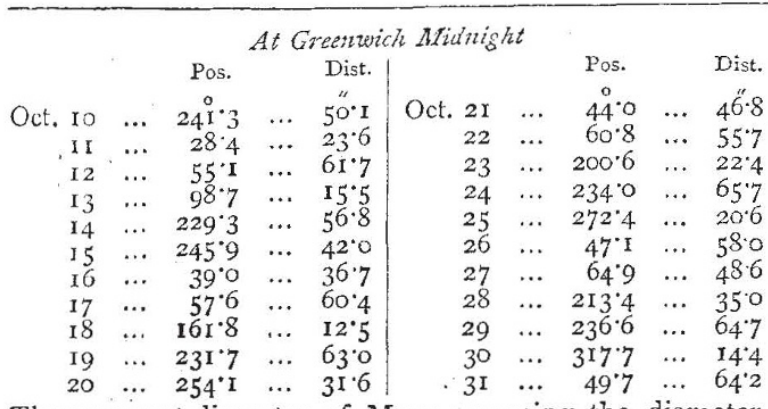

The apparent diameter of Mars, assuming the diameter at the mean distance $9^{\prime \prime} \cdot 415$, will be $17^{\prime \prime} \cdot 8$ on October ro and $19^{\prime \prime} \cdot 5$ on October $3 \mathrm{I}$. The value adopted depends chiefly upon the double-image measures, and is smaller than that introduced in Leverrier's Tables of Mars, which was derived from observations with meridian instruments. The period of revolution of Deimos is $30 \mathrm{~h}$. 17m. 54s., and the mean distance from the centre of Mars 14,500 miles, so that the average orbital velocity is 50 miles per minute. The excentricity appearing to be very small, Prof. Hall assumes a circular orbit for prediction in 1879 .

THE FIRST COMET of I699.-This comet was observed at Paris by Cassini and Maraldi from February 20 to March 2, and at Pekin by the Jesuit missionary, De Fontenay, from February 17 to February 26 . The single orbit which figures in our catalogues was calculated by Lacaille; the following elements by Mr. Hind depending upon the observations of February I9, 24, and March 2, are very similar to Lacaille's, the only noticeable difference being an increase of rather more than $I^{\circ}$ in the inclination :-

Perihelion passage, 1699, January 1333998 G.M.T.

\begin{tabular}{|c|c|c|c|}
\hline Longitude of perihelion & & & 2 i2 $8: 8$ \\
\hline,,,$\quad$ ascending node & $\cdots \quad \cdots$ & $\cdots$ & $32 \mathrm{I} 4 \mathrm{I}^{\circ}$ \\
\hline $\begin{array}{lllll}\text { Inclination } & \ldots & \ldots & \ldots & \ldots \\
\text { Log. perihelion distance } & \ldots\end{array}$ & $\begin{array}{ll}\ldots & \cdots \\
\cdots & \cdots\end{array}$ & $\begin{array}{l}\cdots \\
\cdots\end{array}$ & \\
\hline
\end{tabular}

The rc-examination to a certain extent of the cometary orbits resting upon a single calculation appears by no means a futile work, as was shown by the circumstance pointed out in this column some time since, that Halley had inadvertently given the longitude of the descending node of the comet of 1698 , in his "Synopsis of Cometary Astronomy," in place of that of the ascending node, and the mistake has been continued in all our catalogues.

\section{NOTES}

THE latest conflagration at Irkutsk has destroyed all the libraries of the town-the Public Library, the private one of $\mathrm{M}$. Vaghine (which contained the unpublished MSS. of Gedenstrom), and that of the Siberian branch of the Russian Geographical Society, which latter contained a great variety of works about Siberia, some of them being very rare, a great number of works and MSS. on Buddhism, numerous collections of publications of foreign scientific societies (European, Asiatic, and American) who exchanged their publications with the Siberian branch, and a large assortment of works on physical sciences and natural history. The destruction of this library will be a very great loss to science altogether, if a new one be not immediately created. It would be difficult for a man of science inhabiting a great city or even the smallest town in Western Europe to understand the important services which this library-the only one in Central Asia-has rendered in the development of scientific linowledge and in giving a scientific character to the geographical exploration of Siberia. Many scientific men when staying in Irkutsk have largely made use of the library (we may name among them the well-known president of the Berlin Geographical Society,
Prof. Bastian, and quote his interesting notice on Irkutsk), and the writer of these lines can testify, from his own experience, how immense were the services rendered by this library to him and to his young friends when they began their studies for scientific geographical explorations of Siberia at Irkutsk, i.e., at a distance of some thousand miles from all intellectual centres. We think that all those who have the further development of scientific exploration at heart, should do their utmost to assist in creating a new and good library in that centre for the explora. tion of Siberia.

ON August 20 last, the centenary of the birth of Berzelius was celebrated in a fitting manner at Stockholm. All the principal newspapers commented on the event in leading articles, and reminded their readers in enthusiastic terms that through Linnæeus and Berzelius Sweden obtained citizen-rights in the world of science. At Väfversunda in the province of Smâland, the birth-place of Berzelius, a monument to the great chemist was unveiled on the same day, in the presence of a large concourse of country people.

THE steamship Faraday, which has successfully laid the new transatlantic electric cable from Scilly to Newfoundland, returns to Woolwich to take on board the shore end and the cable to be laid from Newfoundland to America. The Siemens electric works at Charlton are just now busy completing the preparation of these parts, which will be ready by the end of this month, when the Faraday will be mored in the Thames to receive them.

The steamer Dacia left Greenwich a few days ago in order to lay the second electric cable which is to connect Marseilles and Algiers. When this communication has been established the tariff of telegraphic messages between France and Algeria will be diminished by half, being reduced to $r d$. a word instead of $2 d$. as now. It is supposed that the augmentation of traffic with the colony will result in an increased income to the Government.

ON September I snow fell in the village of Neustadt (Holstein).

A TERRIBLE whirlwind is reported from the village of Hopsten, near Münster (Westphalia). It occurred on August 26, at seven P.M. The largest oaks were uprooted and broken down; many houses were partially destroyed, and débris of all kinds marked the path of the atmospheric disturbance, which proceeded in an easterly direction. Strange to say, the most complete calin reigned everywhere around at the time.

PHyLlOXerA has now made its deplorable entry into Italian vineyards. The destructive insect has appeared in the province of Como. The local authorities are making every effort to combat the plague.

Ir was proved some time ago by M. de Heen that, for metals belonging to the same natural group, the product of the coeficient of expansion by the absolute temperature of fusion is a constant quantity. In another memoir just presented to the Belgian Academy, M. de Heen inquires how the coefficient of expansion of water varies with the nature and quantity of substances dissolved in it. He proves that there is also a remarkable relation between the coefficient of expansion of organic liquids belonging to the same homologous series and their boiling point; the product of the one by the other is a constant quantity. In connection with this, M. Spring points out that M. Pictet, guided simply by ideas introduced into science by thermodynamics, has come to the same conclusions as $\mathbf{M}$. de Heen. M. Pictet shows (I) that temperature is represented by the length of calorific oscillations of the molecules of a substance; (2) that the temperatures of fusion of solids correspond to equal lengths of oscillations; and (3) that consequently, the product of the lengths of oscillation by the temperatures of 